Boise State University

ScholarWorks

Kinesiology Faculty Publications and Presentations

Department of Kinesiology

3-1-2009

\title{
Does Cardiac Morphology Predict Plasma Brain Natriuretic Peptide Levels in Adolescent Athletes?
}

\author{
Kurt J. Nilsson \\ Intermountain Orthopaedics and Mountain States Medical, Boise, ID \\ Michael S. Womack \\ Pediatric Cardiology, Boise, ID \\ Ronald Pfeiffer \\ Boise State University \\ Chad Harris \\ Western New Mexico University \\ Mark Debeliso \\ California State University - Monterey Bay
}

This is an author-produced, peer-reviewed version of this article. The final, definitive version of this document can be found online at Clinical Journal of Sport Medicine, published by Lippincott, Williams \& Wilkins. Copyright restrictions may apply. DOI: 10.1097/JSM.0b013e318194f0d6 


\title{
Does Cardiac Morphology Predict Plasma Brain Natriuretic Peptide Levels in Adolescent Athletes?
}

\author{
Kurt J. Nilsson ${ }^{1}$, Michael S. Womack ${ }^{2}$, Ronald P. Pfeiffer ${ }^{3}$, Chad Harris ${ }^{4}$, Mark Debeliso ${ }^{5}$ \\ ${ }^{1}$ Intermountain Orthopaedics and Mountain States Medical, Boise, ID; \\ ${ }^{2}$ Pediatric Cardiology, Boise, ID; \\ ${ }^{3}$ Center for Orthopaedics and Biomechanics Research, Boise State University, Boise, ID; \\ ${ }^{4}$ Department of Health Science and Human Performance, Western New Mexico University; \\ ${ }^{5}$ Department of Kinesiology, California State University - Monterey Bay
}

\begin{abstract}
Objective

The purpose of this study was to establish the relationship of plasma levels of brain natriuretic peptide (BNP) to physiological parameters and cardiac morphological characteristics in a population of young athletes. Our hypothesis is that physiological and cardiac morphological characteristics do not predict BNP levels in adolescent athletes.
\end{abstract}

\section{Design}

Observational study

\section{Setting}

Outpatient hospital

\section{Patients}

30 healthy male adolescent high school football players $(16.0+/-1.1 \mathrm{yrs})$

\section{Intervention}

Physical exam, electrocardiography, plasma BNP measurement by rapid fluorescent immunoassay, and limited echocardiography

\section{Main Outcome Measure}

Null hypothesis: physiologic parameters and cardiac morphology do not predict plasma BNP levels in healthy adolescent football players. Significance level set at $\mathrm{p}<0.05$.

\section{Results}

Plasma BNP for this population was $11.9+/-10.2 \mathrm{pg} \cdot \mathrm{ml}^{-1}$. There was no correlation between BNP and mean arterial pressure $(\mathrm{r}=-0.09, \mathrm{p}=0.64)$, BMI $(\mathrm{r}=0.11, \mathrm{p}=0.57)$, interventricular septal thickness $(\mathrm{r}=-$ $0.15, p=0.44)$, left ventricular wall thickness $(r=0.00, p=0.99)$, relative wall thickness $(r=-0.04, p=$ $0.84)$, left ventricular mass $(r=0.05, p=0.79)$, or left ventricular mass index $(r=0.11, p=0.55)$.

\section{Conclusion}

Plasma BNP levels in healthy adolescent athletes have no correlation to BMI or LV mass, even when corrected for body surface area.

Keywords child; electrocardiography (EKG); cardiac physiology; echocardiography

\section{Introduction.}

Brain, or B-type, natriuretic peptide (BNP) is a 32 amino acid peptide synthesized and secreted from the human heart in response to left ventricular wall stress. It has been shown to cause natriuresis, inhibit the renin-angiotensin-aldosterone system, reduce plasma volume, and modulate vascular tone ${ }^{1}$. Plasma BNP 
levels have been reliably demonstrated to be elevated in several cardiomyopathic states, including systolic and diastolic dysfunction, left ventricular hypertrophy, hypertrophic cardiomyopathy (HCM), and abnormal left ventricular filling patterns ${ }^{1,2}$. BNP levels have been found to be transiently elevated in competitive athletes engaged in endurance events ${ }^{3}$. Although plasma levels of BNP have been studied in healthy adult athletes and found to correlate to LV mass ${ }^{4}$, this is not without contradictory findings ${ }^{5}$. It has been suggested that BNP may be useful to screen for HCM in young athletes ${ }^{6}$.

Bedside testing of plasma BNP levels is rapid, inexpensive, and shows linear measurements of BNP between 5 and $1300 \mathrm{pg} \cdot \mathrm{ml}^{-1}$. Normal values for plasma BNP have been established in healthy controls from neonates to adolescents ${ }^{7}$; however, there are no data currently available regarding correlation of BNP and physiologic characteristics of hearts in young athletes. The purpose of this study is to measure plasma levels of brain natriuretic peptide (BNP) and determine its correlation to physiological parameters and cardiac morphological characteristics in a population of young athletes.

\section{Methods.}

30 males between the ages of 14 and 18 from the local state champion high school football team were asked to voluntarily participate upon scheduling a state-required preparticipation physical exam. For purposes of detecting a meaningful difference in BNP levels from published reports, a cohort of 30 subjects should yield a statistical power $>0.8$, the number being capped at 30 due to availability of study resources. Participants would have been excluded from consideration if they had known cardiac disease or congenital malformation, kidney disease, or history of cardiac surgery; none met exclusion criteria.

Data collection occurred during the off-season (summer). Participants refrained from hard physical activity for 24 hours prior to the study. Study subjects filled out a standardized questionnaire for preparticipation physical exams, had blood pressure, heart rate, height, and weight determination, and underwent physical exam.

A single venous sample of blood was collected from each participant. Plasma BNP levels were then measured according to the manufacturer's instructions within two hours on the Triage ${ }^{\circledR}$ BNP testing meter (Biosite, Inc., San Diego, CA).

Each study participant had an electrocardiogram (EKG) performed which was interpreted by a board certified pediatric cardiologist. Each study participant underwent limited left ventricular echocardiography while the pediatric cardiologist was present to oversee the procedure and interpret the results. The pediatric cardiologist was blinded to the results of the BNP measurement.

LV mass index was calculated by dividing the LV mass by body surface area (BSA).

Left ventricular wall thickness $=$ IVSTd + LVPWd

Relative wall thickness $=$ IVSTd + LVPWd $/$ LVEDD

Descriptive statistics were employed to define the cohort, and EKG findings were described. BNP levels were compared with univariate linear regression analysis to BMI, mean arterial pressure, and echocardiographic parameters. Significance level defined as $\mathrm{p}<0.05$. All statistics were completed on SPSS v.10.0 (SPSS, Inc., Chicago, IL).

\section{Ethical considerations.}

Institutional Review Board approval was obtained from Boise State University prior to study initiation. Written informed consent was obtained from all participants and their legal guardians. 


\section{Results.}

Characteristics of study subjects are presented in Table 1. There were no abnormal cardiovascular findings on any physical exam.

Electrocardiographic characteristics of study subjects are presented in Table 2. No echocardiographic abnormalities were found.

Plasma BNP measurements (mean +/- SD) were $11.9+/-10.2 \mathrm{pg} \cdot \mathrm{ml}^{-1}$ and ranged from undetectable $(<5$ $\mathrm{pg} \cdot \mathrm{ml}^{-1}$ ) to $41.7 \mathrm{pg} \cdot \mathrm{ml}^{-1}$.

Echocardiographic characteristics of study subjects are presented in Table 3.

There was no significant correlation between BNP values and mean arterial pressure $(r=-0.09, p=0.64)$, BMI $(r=0.11, p=0.57)$, interventricular septal thickness $(r=-0.15, p=0.44), L V$ wall thickness $(r=0.00$, $\mathrm{p}=0.99)$, relative wall thickness $(\mathrm{r}=-0.04 \mathrm{p}=0.84), \mathrm{LV}$ mass $(\mathrm{r}=0.05, \mathrm{p}=0.79)$, or LV mass index $(\mathrm{r}=$ $0.11, \mathrm{p}=0.55)$. Scatter diagram is shown in Figure 1 .

\section{Discussion.}

Our results document levels of plasma BNP as well as the electrocardiographic and echocardiographic characteristics of a healthy young male group of athletes, and find no significant correlation between the plasma BNP levels measured in these athletes and BMI, MAP, or observed cardiac parameters.

Morphologic evaluation of the heart has been reliably conducted since the early 1970's with echocardiography, the noninvasive use of ultrasound-generated images of the heart to quantify cardiac dimensions and dynamic function ${ }^{8}$. Since that time, ranges of cardiac dimensions have been studied and described in virtually all populations, including children ${ }^{9,10}$, athletes ${ }^{4,11-17}$, and patients with HCM $^{18,19}$. Echocardiography has also allowed the morphologic characterization of athlete's heart syndrome, a constellation of physiologic adaptations to exercise that maintains or enhances cardiac function in response to stress. ${ }^{20}$ The development of biventricular enlargement in athlete's heart syndrome presents a challenge in differentiating young athletes with HCM from those with cardiac adaptation to exercise. ${ }^{21}$ Reference echocardiographic measurements in children and adolescents have been historically based on normalizing values to body surface area ${ }^{9,10}$. Studies describing norms and upper limits of cardiac measurements in young athletes are given for comparison in Table 4. Echocardiography in our study population (Table 3) did not reveal any pathologic cardiac lesions, and measurements obtained were mostly below the upper limits of normal in young athletes.

The EKG findings in our population of athletes were in keeping with prior descriptions of athletic subjects 20 and of normal adolescents. All of the features noted by electrocardiography have been found in populations of athletes without pathologic cardiac changes, and have been attributed to physiologic adaptation to enhance cardiac function, including increased parasympathetic tone and biventricular enlargement ${ }^{20}$. This underscores an important point about electrocardiography in athletes and adolescents: benign aberrances in EKG's are common, and may demonstrate an electrophysiologic adaptation to exercise that has not grossly manifested as a morphologic adaptation. In this regard, these EKG findings should be viewed as normal.

The Breathing Not Properly study established BNP levels $>100 \mathrm{pg} / \mathrm{ml}$ to be sensitive at differentiating CHF from lung disease in the emergency department ${ }^{22}$; this has been further stratified to differentiate "gray zone" BNP levels from 100-500 $\mathrm{pg} / \mathrm{ml}$ in the REDHOT study ${ }^{23}$. In practice, utilizing BNP for heart failure diagnosis and monitoring must take into consideration factors such as age and gender, but there are generally no situations where BNP levels are routinely and persistently elevated $>100 \mathrm{pg} / \mathrm{ml}$ without underlying cardiac pathology ${ }^{24}$. We were able to identify three studies published specifically to describe normal levels of BNP in neonates to adolescents ${ }^{7,25,26}$. Several studies have reported the value of using plasma BNP levels in children to assess status of various cardiac disorders, including VSD ${ }^{27}$, heart 
transplant $^{28}$, CHF vs. lung disease ${ }^{29}$, chemotherapy ${ }^{30}$, Duchenne's muscular dystrophy ${ }^{31}$, Kawasaki $^{32}$, and congenital heart disease ${ }^{33,34}$. These studies have reported BNP levels from $20-100 \mathrm{pg} / \mathrm{ml}$ as sufficiently sensitive and specific to discern a clinical difference. While the utility of BNP measurement in HCM has yet to be fully elucidated 35,36 , it has been suggested that increased expression of BNP may be a characteristic feature of HCM2. BNP values from our study population of $11.9+/-10.2 \mathrm{pg} \cdot \mathrm{ml}^{-1}$ are comparable to prior studies of BNP levels in normal adolescents 7, 26 (Table 5). To our knowledge, this is the first study on BNP levels in a population of adolescent athletes.

It should be acknowledged that this study was limited by a small sample size and the fact that no subjects showed abnormal cardiac structural changes. Results should be interpreted in this light and used as a basis for further studies on the subject.

\section{Conclusions.}

Our findings demonstrate that adolescent athletes have similar levels of BNP when compared to normal healthy children, and imply there is no correlation between LV morphology and BNP levels in a young healthy athletic population. Future research should evaluate BNP levels in other athletic groups and in athletes with echocardiographic changes of increased LV mass, to better define the role of BNP levels in detecting cardiac pathology.

\section{Acknowledgments.}

The authors are grateful to the subjects who participated in this study. We are also grateful to Billie McKown, Sam Lewis, and Danielle Walk for their assistance in data acquisition, and to St. Luke's Hospital, Boise, ID for facilities support.

Supported by a grant from Biosite, Inc. San Diego, CA. Findings in this study do not constitute an endorsement of Biosite, Inc. by the authors.

\section{Conflicts of interest.}

All authors report no conflicting interest

\section{References}

1. Stoupakis G, Klapholz M. Natriuretic peptides: biochemistry, physiology, and therapeutic role in heart failure. Heart Dis. May-Jun 2003;5(3):215-223.

2. Nishigaki K, Tomita M, Kagawa K, et al. Marked expression of plasma brain natriuretic peptide is a special feature of hypertrophic obstructive cardiomyopathy. J Am Coll Cardiol. Nov 1 1996;28(5):1234-1242.

3. Ohba H, Takada H, Musha H, et al. Effects of prolonged strenuous exercise on plasma levels of atrial natriuretic peptide and brain natriuretic peptide in healthy men. Am Heart J. May 2001;141(5):751-758.

4. Date H, Imamura T, Onitsuka H, et al. Differential increase in natriuretic peptides in elite dynamic and static athletes. Circ J. Aug 2003;67(8):691-696.

5. Almeida SS, Azevedo A, Castro A, et al. B-type natriuretic peptide is related to left ventricular mass in hypertensive patients but not in athletes. Cardiology. 2002;98(3):113-115.

6. Khan K, Talwar S. Screening for familial hypertrophic cardiomyopathy using brain natriuretic peptide. Eur Heart J. Apr 1999;20(7):550

7. Koch A, Singer H. Normal values of B type natriuretic peptide in infants, children, and adolescents. Heart. Aug 2003;89(8):875-878. 
8. Mistry DJ, Kramer CM. Imaging of cardiopulmonary diseases. Clin Sports Med. Jan 2003;22(1):197212.

9. Henry WL, Ware J, Gardin JM, Hepner SI, McKay J, Weiner M. Echocardiographic measurements in normal subjects. Growth-related changes that occur between infancy and early adulthood. Circulation. Feb 1978;57(2):278-285.

10. Kampmann C, Wiethoff CM, Wenzel A, et al. Normal values of M mode echocardiographic measurements of more than 2000 healthy infants and children in central Europe. Heart. Jun 2000;83(6):667-672.

11. Telford RD, McDonald IG, Ellis LB, Chennells MH, Sandstrom ER, Fuller PJ. Echocardiographic dimensions in trained and untrained 12-year-old boys and girls. J Sports Sci. Spring 1988;6(1):4957.

12. Pelliccia A, Maron BJ. Outer limits of the athlete's heart, the effect of gender, and relevance to the differential diagnosis with primary cardiac diseases. Cardiol Clin. Aug 1997;15(3):381-396.

13. Pavlik G, Olexo Z, Osvath P, Sido Z, Frenkl R. Echocardiographic characteristics of male athletes of different age. Br J Sports Med. Apr 2001;35(2):95-99.

14. Somauroo JD, Pyatt JR, Jackson M, Perry RA, Ramsdale DR. An echocardiographic assessment of cardiac morphology and common ECG findings in teenage professional soccer players: reference ranges for use in screening. Heart. Jun 2001;85(6):649-654.

15. Maron BJ. Structural features of the athlete heart as defined by echocardiography. J Am Coll Cardiol. Jan 1986;7(1):190-203.

16. Yamazaki H, Senju Y, Kinoshita N, Katsukawa F, Onishi S. Plasma brain natriuretic peptide in athletes. Am J Cardiol. Jun 1 2000;85(11):1393-1394.

17. Sharma S, Maron BJ, Whyte G, Firoozi S, Elliott PM, McKenna WJ. Physiologic limits of left ventricular hypertrophy in elite junior athletes: relevance to differential diagnosis of athlete's heart and hypertrophic cardiomyopathy. J Am Coll Cardiol. Oct 16 2002;40(8):1431-1436.

18. Seward JB, Tajik AJ. Primary cardiomyopathies: classification, pathophysiology, clinical recognition and management. Cardiovasc Clin. 1980;10(3):199-230.

19. Sherrid MV, Chaudhry FA, Swistel DG. Obstructive hypertrophic cardiomyopathy: echocardiography, pathophysiology, and the continuing evolution of surgery for obstruction. Ann Thorac Surg. Feb 2003;75(2):620-632.

20. Pelliccia A, Di Paolo FM, Maron BJ. The athlete's heart: remodeling, electrocardiogram and preparticipation screening. Cardiol Rev. Mar-Apr 2002;10(2):85-90.

21. Maron BJ, Pelliccia A, Spirito P. Cardiac disease in young trained athletes. Insights into methods for distinguishing athlete's heart from structural heart disease, with particular emphasis on hypertrophic cardiomyopathy. Circulation. Mar 1 1995;91(5):1596-1601

22. McCullough PA, Nowak RM, McCord J, et al. B-type natriuretic peptide and clinical judgment in emergency diagnosis of heart failure: analysis from Breathing Not Properly (BNP) Multinational Study. Circulation. Jul 23 2002;106(4):416-422

23. Brenden CK, Hollander JE, Guss D, et al. Gray zone BNP levels in heart failure patients in the emergency department: results from the Rapid Emergency Department Heart Failure Outpatient Trial (REDHOT) multicenter study. Am Heart J. May 2006;151(5):1006-1011. 
24. Burke MA, Cotts WG. Interpretation of B-type natriuretic peptide in cardiac disease and other comorbid conditions. Heart Fail Rev. Mar 2007;12(1):23-36

25. Ationu A, Carter ND. Brain and atrial natriuretic peptide plasma concentrations in normal healthy children. Br J Biomed Sci. Jun 1993;50(2):92-95.

26. Yoshibayashi M, Kamiya T, Saito Y, et al. Plasma brain natriuretic peptide concentrations in healthy children from birth to adolescence: marked and rapid increase after birth. Eur J Endocrinol. Aug 1995;133(2):207-209.

27. Suda K, Matsumura M, Matsumoto M. Clinical implication of plasma natriuretic peptides in children with ventricular septal defect. Pediatr Int. Jun 2003;45(3):249-254.

28. Claudius I, Lan YT, Chang RK, Wetzel GT, Alejos J. Usefulness of B-type natriuretic peptide as a noninvasive screening tool for cardiac allograft pathology in pediatric heart transplant recipients. Am J Cardiol. Dec 1 2003;92(11):1368-1370.

29. Koulouri S, Acherman RJ, Wong PC, Chan LS, Lewis AB. Utility of B-Type Natriuretic Peptide in Differentiating Congestive Heart Failure from Lung Disease in Pediatric Patients with Respiratory Distress. Pediatr Cardiol. Apr 2004.

30. Hayakawa H, Komada Y, Hirayama M, Hori H, Ito M, Sakurai M. Plasma levels of natriuretic peptides in relation to doxorubicin-induced cardiotoxicity and cardiac function in children with cancer. Med Pediatr Oncol. Jul 2001;37(1):4-9.

31. Mori K, Manabe T, Nii M, Hayabuchi Y, Kuroda Y, Tatara K. Plasma levels of natriuretic peptide and echocardiographic parameters in patients with Duchenne's progressive muscular dystrophy. Pediatr Cardiol. Mar-Apr 2002;23(2):160-166.

32. Kurotobi S, Kawakami N, Shimizu K, et al. Brain natriuretic peptide as a hormonal marker of ventricular diastolic dysfunction in children with Kawasaki disease. Pediatr Cardiol. Jul-Aug 2005;26(4):425-430.

33. Cowley CG, Bradley JD, Shaddy RE. B-Type Natriuretic Peptide Levels in Congenital Heart Disease. Pediatr Cardiol. Jan 232004.

34. Law YM, Keller BB, Feingold BM, Boyle GJ. Usefulness of plasma B-type natriuretic peptide to identify ventricular dysfunction in pediatric and adult patients with congenital heart disease. Am J Cardiol. Feb 15 2005;95(4):474-478.

35. Binder J, Ommen SR, Chen HH, Ackerman MJ, Tajik AJ, Jaffe AS. Usefulness of brain natriuretic Peptide levels in the clinical evaluation of patients with hypertrophic cardiomyopathy. Am J Cardiol. Aug 15 2007;100(4):712-714.

36. Maron BJ, Tholakanahalli VN, Zenovich AG, et al. Usefulness of B-type natriuretic peptide assay in the assessment of symptomatic state in hypertrophic cardiomyopathy. Circulation. Mar 2 2004;109(8):984-989.

37. Kunii Y, Kamada M, Ohtsuki S, et al. Plasma brain natriuretic peptide and the evaluation of volume overload in infants and children with congenital heart disease. Acta Med Okayama. Aug 2003;57(4):191-197.

38. Ohuchi $\mathrm{H}$, Takasugi $\mathrm{H}$, Ohashi $\mathrm{H}$, et al. Stratification of pediatric heart failure on the basis of neurohormonal and cardiac autonomic nervous activities in patients with congenital heart disease. Circulation. Nov 11 2003;108(19):2368-2376. 

doi: 10.1097/JSM.0b013e318194f0d6

Table 1 Characteristics of study subjects. Values are mean +/- SD.

$\begin{array}{lc}\text { Age }(\mathrm{yrs}) & 16.0+/-1.1 \\ \mathrm{BMI} & 23.8+/-3.1 \\ \mathrm{BSA}\left(\mathrm{m}^{2}\right) & 1.9+/-0.2 \\ \mathrm{HR} & 62.6+/-8.7 \\ \text { Systolic blood pressure } & 118.9+/-12.3 \\ \text { Diastolic blood pressure } & 69.6+/-7.9 \\ \text { MAP } & 86+/-7.8\end{array}$

Table 2 Frequency of electrocardiographic findings in study subjects

\begin{tabular}{lc} 
Sinus arrhythmia & 13 \\
Bradycardia (HR < $60 \mathrm{bpm})$ & 12 \\
Normal & 7 \\
Left ventricular hypertrophy (R wave in aVL > $11 \mathrm{~mm})$ & 2 \\
Early repolarization (benign ST segment elevation) & 2 \\
Intraventricular conduction delay (QRS > 0.10 s) & 2 \\
Rightward axis (90-120 degrees) & 1 \\
Short PR (PR < 0.12 s) & 1 \\
Fusion complexes with ventricular escape & 1 \\
\hline
\end{tabular}

Table 3 Echocardiographic measurements. IVSTd = interventricular septal thickness in diastole; LVPWd $=L V$ posterior wall thickness in diastole; $L V E D D=$ left ventricular end diastolic dimension. Values given as mean +/- SD.

\begin{tabular}{|lc|}
\hline $\mathrm{N}$ & 30 \\
Median Age $(\mathrm{yrs})$ & $16.0+/-1.1$ \\
IVSTd $(\mathrm{mm})$ & $8.4+/-1.6$ \\
LVPWd $(\mathrm{mm})$ & $9.2+/-1.6$ \\
LVEDD $(\mathrm{mm})$ & $51.9+/-4.1$ \\
LV wall thickness $(\mathrm{mm})$ & $17.6+/-2.8$ \\
LV mass $(\mathrm{g})$ & $190.2+/-38.7$ \\
LV mass index $\left(\mathrm{g} / \mathrm{m}^{2}\right)$ & $98.3+/-17.6$ \\
\hline
\end{tabular}



doi: 10.1097/JSM.0b013e318194f0d6

Table 4. Echocardiographic measurements from other studies for comparison, presented as mean +/- SD. See Table 3 for abbreviation key. *Normative data presented by body surface area (BSA); these data are presented for a BSA of $2.0 \mathrm{~m}^{2}$. † A review of 25 prior studies.

\begin{tabular}{|c|c|c|c|c|c|c|c|}
\hline Study & $\mathrm{n}$ & $\begin{array}{c}\text { Median Age } \\
\text { (yrs) }\end{array}$ & $\begin{array}{l}\begin{array}{l}\text { IVSTd } \\
(\mathrm{mm})\end{array} \\
\end{array}$ & $\begin{array}{l}\text { LVPWd } \\
(\mathrm{mm})\end{array}$ & $\begin{array}{l}\text { LVEDD } \\
(\mathrm{mm})\end{array}$ & LV mass $(\mathrm{g})$ & $\begin{array}{c}\text { LV mass index } \\
\left(\mathrm{g} \cdot \mathrm{m}^{-2}\right)\end{array}$ \\
\hline Kampmann ${ }^{* 10}$ & 2036 & & $\begin{array}{c}9.3+/- \\
1.25\end{array}$ & $8.1+/-1.5$ & $53.4+/-4$ & & \\
\hline Maron $t^{15}$ & $\begin{array}{l}381- \\
701\end{array}$ & 23 & 10.4 & 10.7 & 53.9 & 265 & \\
\hline $\begin{array}{l}\text { Somauroo, et } \\
\mathrm{al}^{14}\end{array}$ & 171 & 16.7 & $\begin{array}{c}10.3+/- \\
1.4\end{array}$ & $\begin{array}{c}10.0+/- \\
1.5\end{array}$ & $\begin{array}{c}51.4+/- \\
3.9\end{array}$ & $229.8+/-44$ & \\
\hline $\begin{array}{l}\text { Sharma, et } \\
\mathrm{al}^{17}\end{array}$ & 720 & 15.7 & $9.4+/-1.3$ & $9.3+/-1.3$ & $\begin{array}{c}50.8+/- \\
3.7\end{array}$ & & $113+/-33.3$ \\
\hline $\begin{array}{l}\text { Date - } \\
\text { Dynamic }^{4}\end{array}$ & 20 & $26.8+/-8.5$ & & & & $318.3+/-48$ & \\
\hline Date - Static ${ }^{4}$ & 15 & $24.7+/-2.6$ & & & & $\begin{array}{c}496.2+/- \\
114.8\end{array}$ & \\
\hline Almeida, et al ${ }^{5}$ & 8 & $29.9+/-0.8$ & & & & & $180.7+/-10.3$ \\
\hline $\begin{array}{l}\text { Yamazaki, et } \\
\mathrm{al}^{16}\end{array}$ & 7 & $20+/-1$ & & & & & $152.3+/-16.2$ \\
\hline
\end{tabular}

Table 5. Plasma BNP measurements from previous studies of children and adolescents. BNP values given as mean $+/-S D$.

\begin{tabular}{|c|c|c|c|}
\hline Study & $\mathrm{n}$ & Age (yrs.) & BNP $\left(\mathrm{pg} \cdot \mathrm{ml}^{-1}\right)+/-\mathrm{SD}$ \\
\hline Ationu \& Carter ${ }^{25}$ & 20 & $10.0-15.0$ & $31+/-4$ \\
\hline Koch \& Singer $^{7}$ & 31 & $10-17.6$ & $5.1+/-3.5$ \\
\hline Yoshibayashi, et al. ${ }^{26}$ & 40 & $0-16$ & $9.3+/-4.8$ \\
\hline Kunii, et al. ${ }^{37}$ & 253 & $0-16$ & $5.3+/-3.8$ \\
\hline Ohuchi, et al. ${ }^{38}$ & 54 & $1.0-40$ & $4+/-4$ \\
\hline Law, et al. ${ }^{34}$ & 17 & $0.3-18.5$ & $22+/-5$ \\
\hline
\end{tabular}

Figure 1 Scatter diagram of physiologic paramaeters vs. BNP levels 